\title{
The impact of methodological and temporal variation on infarct size quantification in acute myocardial infarction with late enhancement CMR
}

\author{
Nishat Siddiqi ${ }^{1 *}$, Christopher J Neil ${ }^{1}$, Jagpal Baljit ${ }^{1}$, Jemma Hudson², Michael P Frenneaux', Dana K Dawson ${ }^{1}$ \\ From 18th Annual SCMR Scientific Sessions \\ Nice, France. 4-7 February 2015
}

\section{Background}

Infarct size (IS) is one of the most important predictors of outcome after acute myocardial infarction (AMI) and can be detected in vivo with Late Enhancement CMR (LGE). However, the most consistent method of LGE quantification is yet to be determined.

\section{Methods}

55 patients with reperfused, first acute ST-elevation AMI underwent LGE-CMR on a Philips Achieva 3T scanner at 1 week and 6 months post AMI. IS was expressed as a percentage of LV volume and measured at both time points using: manual planimetry, signal intensity threshold indicating LGE set at 2, 3 and 5 standard deviations (SD) above the remote myocardium and the full width at half maximum (FWHM) technique, which uses half the maximal signal within the scar as the threshold. The relationship between all measures of IS and final (6 month) LV ejection fraction (LV EF) and LV end diastolic volume (LV EDV) was evaluated using Spearman correlations.

\section{Results}

Mean age was $61 \pm 11$ years and $63 \%$ were male. All techniques showed a consistent reduction in IS between the early and six month scans (Figure) with the difference of early-to-late mean IS in decreasing order of: $10.3 \%$ for FWHM, $10 \%$ for manual, $8.5 \%$ for 2 SD, $4.6 \%$ for $3 \mathrm{SD}$ and $1.4 \%$ for $5 \mathrm{SD}$ - which showed least timedependent variation.
Inter and intra observer variabilities using Intra-class Correlation (ICC) were $\geq 0$ [ddawson1] .9 for all methods $(\mathrm{p}<0.001)$.

As a general characteristic, all IS methods were better predictors of final LV EF than final LVEDV (Tables 1 and 2). On the early scan manual planimetry performed best as a predictor of 6 month LVEF whereas on the 6 month scan FWHM performed best as a correlate of LVEF on the same scan (Table 2).

\section{Conclusions}

FWHM, manual planimetry and 5SD had good agreement for final (6 month) IS, and 5SD showed least time-dependent variation. Manual planimetry is a better predictor of final EF when measured early whereas

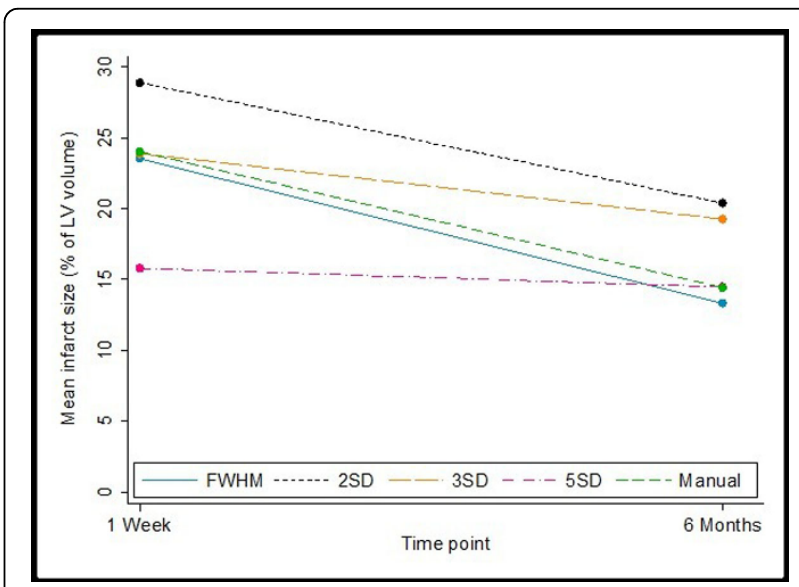

Figure 1 Mean IS at one week and six months using the different methods

${ }^{1}$ Cardiology, University of Aberdeen, Aberdeen, UK

Full list of author information is available at the end of the article 
Table 1 Spearmans Correlation Coefficient of IS measured at 1 week and EF and EDV at 6 months and IS and EF and EDV at $\mathbf{6}$ months ( $\mathbf{p}<\mathbf{0 . 0 0 1}$ for all)

\begin{tabular}{cccccc}
\hline METHOD & EF 6 MONTHS & EDV 6 MONTHS & METHOD & EF 6MONTHS & EDV 6 MONTHS \\
\hline FWHM 1 WEEK & -0.55 & 0.38 & FWHM 6 MONTHS & -0.61 & 0.42 \\
\hline 2SD 1 WEEK & -0.53 & 0.53 & 2SD 6 MONTHS & -0.52 & 0.41 \\
\hline 3SD 1 WEEK & -0.52 & 0.53 & 3SD 6 MONTHS & -0.54 & 0.44 \\
\hline 5SD 1 WEEK & -0.40 & 0.50 & 5SD 6 MONTHS & -0.59 & 0.48 \\
\hline MANUAL 1 WEEK & -0.61 & 0.48 & MANUAL 6 MONTHS & -0.49 & 0.41 \\
\hline
\end{tabular}

FWHM is a better correlate of EF when measured form late scans.

\section{Funding}

This project was funded by a grant from the MRC(UK).

\section{Authors' details}

${ }^{1}$ Cardiology, University of Aberdeen, Aberdeen, UK. ${ }^{2}$ Health Sciences

Research Unit, University of Aberdeen, Aberdeen, UK.

Published: 3 February 2015

\section{doi:10.1186/1532-429X-17-S1-P149}

Cite this article as: Siddiqi et al:: The impact of methodological and temporal variation on infarct size quantification in acute myocardial

infarction with late enhancement CMR. Journal of Cardiovascular Magnetic

Resonance 2015 17(Suppl 1):P149.

Submit your next manuscript to BioMed Central and take full advantage of:

- Convenient online submission

- Thorough peer review

- No space constraints or color figure charges

- Immediate publication on acceptance

- Inclusion in PubMed, CAS, Scopus and Google Scholar

- Research which is freely available for redistribution

Submit your manuscript at www.biomedcentral.com/submit 